\title{
Hydrogen-Rich Gas Production by Sorption Enhanced Steam Reforming of Woodgas Containing TAR over a Commercial Ni Catalyst and Calcined Dolomite as $\mathrm{CO}_{2}$ Sorbent
}

\author{
Mario Sisinni ${ }^{1}$, Andrea Di Carlo ${ }^{2, *}$, Enrico Bocci ${ }^{3}$, Andrea Micangeli ${ }^{2}$ and Vincenzo Naso ${ }^{1,2}$ \\ 1 CIRPS - Interuniversity Research Centre on Sustainable Development, Piazza San Pietro in Vincoli \\ 10, Rome 00184, Italy; E-Mail: mario.sisinni@gmail.com \\ 2 Department of Mechanical and Aerospace Engineering, Sapienza University of Rome, Via \\ Eudossiana 18, Rome 00184, Italy; E-Mails: andrea.micangeli@uniroma1.it (A.M.); \\ vincenzo.naso@uniroma1.it(V.N.) \\ 3 Energy and Mechanic Department, Marconi University of Rome, Via Virgilio. 8, Rome 00193, \\ Italy; E-Mail: e.bocci@unimarconi.it \\ * Author to whom correspondence should be addressed; E-Mail: andrea.dicarlo@uniroma1.it; \\ Tel.: +39-06-44585400.
}

Received: 15 May 2013; in revised form: 24 June 2013 / Accepted: 26 June 2013 /

Published: 1 July 2013

\begin{abstract}
The aim of this work was the evaluation of the catalytic steam reforming of a gaseous fuel obtained by steam biomass gasification to convert topping atmosphere residue (TAR) and $\mathrm{CH}_{4}$ and to produce pure $\mathrm{H}_{2}$ by means of a $\mathrm{CO}_{2}$ sorbent. This experimental work deals with the demonstration of the practical feasibility of such concepts, using a real woodgas obtained from fluidized bed steam gasification of hazelnut shells. This study evaluates the use of a commercial Ni catalyst and calcined dolomite $(\mathrm{CaO} / \mathrm{MgO})$. The bed material simultaneously acts as reforming catalyst and $\mathrm{CO}_{2}$ sorbent. The experimental investigations have been carried out in a fixed bed micro-reactor rig using a slipstream from the gasifier to evaluate gas cleaning and upgrading options. The reforming/sorption tests were carried out at $650{ }^{\circ} \mathrm{C}$ while regeneration of the sorbent was carried out at $850{ }^{\circ} \mathrm{C}$ in a nitrogen environment. Both combinations of catalyst and sorbent are very effective in TAR and $\mathrm{CH}_{4}$ removal, with conversions near $100 \%$, while the simultaneous $\mathrm{CO}_{2}$ sorption effectively enhances the water gas shift reaction producing a gas with a hydrogen volume fraction of over $90 \%$. Multicycle tests of reforming $/ \mathrm{CO}_{2}$ capture and regeneration were performed to verify the stability of the catalysts and sorbents to remove TAR and capture $\mathrm{CO}_{2}$ during the duty cycle.
\end{abstract}


Keywords: biomass gasification; TAR steam reforming; $\mathrm{CO}_{2}$ capture; fluidized bed

\section{Introduction}

Among renewable energy sources biomass is attracting increasing attention due to its abundance and low cost. Among all technologies, biomass gasification is intended to perform an important role in the production of a $\mathrm{H}_{2}$-rich syngas [1]. Biomass gasification (with steam, and/or oxygen) is a thermochemical process that produces a fuel syngas rich in hydrogen and carbon monoxide, with additional significant quantities of carbon dioxide and methane. An undesirable product is Topping Atmosphere Residue (TAR), that is a complex mixture of cyclic and polycyclic aromatic hydrocarbons [2], known for its toxicity and cancerous properties. Unacceptable levels of TAR cause operational problems in downstream processes, such as internal combustion engines or gas turbines [3].

Catalytic steam reforming seems to represent the best method to both reform methane and eliminate TAR compounds, converting them into $\mathrm{H}_{2}$ and raising the energy content of syngas [4]. Many authors have studied the catalytic reforming of TAR analyzing different types of catalysts and using representative TAR compounds (such as toluene, naphthalene, etc.) in order to enhance $\mathrm{H}_{2}$ yields and improve catalyst endurance towards deactivation by carbon deposition or sintering [5-8].

Furthermore, with the aim of maximize the $\mathrm{H}_{2}$ content in the produced gas, a $\mathrm{CO}_{2}$ sorbent can be used in the gasification chamber in order to capture $\mathrm{CO}_{2}$ as soon as it is produced. The removal of $\mathrm{CO}_{2}$ shifts the thermodynamic equilibrium of the water gas shift (WGS) reaction to the hydrogen product. Using $\mathrm{Ni}$ as metal catalyst, good results have been reported in the sorption enhanced steam methane reforming [9-12] with hydrogen molar fractions higher than $95 \%$ and $\mathrm{CH}_{4}$ almost completely reformed with an operative temperature that varied between $600{ }^{\circ} \mathrm{C}$ and $700{ }^{\circ} \mathrm{C}$. In recent years several papers have reported gasification processes that include $\mathrm{CO}_{2}$ capture with calcium oxide-based sorbents [13]. $\mathrm{CaO}$ reacts with carbon dioxide to form calcium carbonate in an exothermic reaction. Hence, to ensure continuity to the process, the sorbent has to be regenerated by the reverse endothermic reaction of $\mathrm{CaCO}_{3}$ calcination:

Carbonation

Calcination

$$
\begin{aligned}
& \mathrm{CaO}(\mathrm{s})+\mathrm{CO}_{2}(\mathrm{~g}) \rightarrow \mathrm{CaCO}_{3}(\mathrm{~s}) \\
& \mathrm{CaCO}_{3}(\mathrm{~s}) \rightarrow \mathrm{CaO}(\mathrm{s})+\mathrm{CO}_{2}(\mathrm{~g})
\end{aligned}
$$

$$
\Delta H_{923}^{0}=-1705 \mathrm{~kJ} / \mathrm{mol}
$$$$
\Delta H_{923}^{0}=+1705 \mathrm{~kJ} / \mathrm{mol}
$$

The gas obtained, rich in hydrogen, could be exploited in high efficiency power generation devices like GT, MCFC or SOFC [14-21]. At the moment one of the most efficient gasification technologies is likely to be the dual fluidized bed system, consisting of the circulation of the bed material between two different reactors, dividing gasification and char combustion reactions [8]. Due to this configuration, it is possible to exploit the bed material as a heat carrier, in order to enhance heat exchange between the two reactors and favour both gasification and combustion reactions. Moreover, supplying air to the combustor only and steam to the primary reactor, is it possible to increase the Lower Heating Value of the syngas, that is no more diluted with the $\mathrm{N}_{2}$ present in the air $[8,19]$.

The addition of a $\mathrm{CaO}$ sorbent in the bed material lets the sorbent be continuously regenerated in the combustion reactor after carbonation due to $\mathrm{CO}_{2}$ capture in the gasifier. Furthermore both the delivery of the hot regenerated sorbent to the gasifier and the exothermic $\mathrm{CO}_{2}$ absorption provides 
additional heat to the endothermic gasification reactions, decreasing the amount of circulating material needed; contemporary, exothermic combustion provides heat for the regeneration of the sorbent, ensuring a better thermal control of the whole process [13,22,23].

Therefore, combining catalytic reforming and $\mathrm{CO}_{2}$ absorption through contemporary use of $\mathrm{CaO}$ sorbent and catalyst as bed material in fluidised bed reactors (in a process called Sorption Enhanced Steam Reforming - SESR) it is possible to obtain the best result in $\mathrm{H}_{2}$-rich syngas production [24].

A typical calcium oxide based sorbent studied in the literature is dolomite, which presents great $\mathrm{CO}_{2}$ sorption properties [10]. Unfortunately these types of sorbents suffer from the conditions reached in both gasifier and combustion chamber, such as thermal stress and mechanical friction (especially in fluidized bed where bed material suffers of attrition problems). Many authors observed high decay in sorbent reactivity due to multiple $\mathrm{CO}_{2}$ capture-regeneration cycles, accompanied by a significant decrease in porosity and surface area $[10,11,25,26]$. As a result, the literatures report many attempts to improve both reactivity and endurance of sorbents $[9,13,27,28]$. The greatest efforts are directed to the synthesis of tailored binders or support for $\mathrm{CaO}$ to enhance its reactivity and stability. Di Felice et al. [29,30], for example, have reported successful results in single cycle $\mathrm{CO}_{2}$ capture and TAR reduction with dolomite impregnated by nickel or iron, using toluene and 1-methyl naphthalene as model compound for TAR produced during biomass gasification and in multi-cycle Sorption Enhanced Steam Methane Reforming too [24].

In the present work the behaviour of a commercial Ni catalyst (HiFUEL R110, Johnson Matthey Plc, Alfa Aesar, Ward Hill, MA, USA), mixed with calcined dolomite as sorbent ( $5 \mathrm{wt} \% \mathrm{Ni}$ ) has been investigated. The material has been tested in the secondary fixed bed reactor of a gasification test rig, continuously fed with produced syngas and maintained at $650{ }^{\circ} \mathrm{C}$. High hydrocarbons produced by hazelnut shells gasification at $850^{\circ} \mathrm{C}$ have been used as TAR model compound [31]. The efficiency of the material as both $\mathrm{CO}_{2}$ sorbent and TAR converter and its endurance have been evaluated observing the $\mathrm{H}_{2}$ response curve (as described by Ortiz and Harrison [32,33]) and the amount of TAR inside the syngas during four subsequent absorption-calcination cycles.

\section{Experimental}

\subsection{Materials}

The material used for SESR tests consists of a commercial HiFUEL R110 nickel catalyst mixed with calcined dolomite kindly provided by Pilkington (see Table 1 for elemental analysis and specific surface area of dolomite).

Table 1. Elemental analysis of fresh dolomite; and specific surface area of calcined dolomite.

\begin{tabular}{cccc}
\hline Dolomite Characterisation & Fe & CaO & MgO \\
\hline Elemental analysis $(w t \%$ fresh dolomite $)$ & 0.01 & 30.39 & 20.56 \\
\hline Specific surface area of calcined dolomite $\left(\mathrm{m}^{2} / \mathrm{g}\right)$ & - & - & 15.2 \\
\hline
\end{tabular}




\subsection{Catalyst Characterization}

The catalyst has been characterized X-ray fluorescence. Composition of the commercial Ni catalyst has been evaluated by X-ray fluorescence analysis, performed on a SPECTRO X-LAB 2000 instrument (SPECTRO Analytical Instruments $\mathrm{GmbH}$., Kleve, Germany). Values of $\mathrm{Ni}$ and $\mathrm{Al}$ concentration for the catalyst before reduction are reported in Table 2. From the data of Table 2 the amount of metallic $\mathrm{Ni}$ after reduction was $16.6 \%$ by weight.

Table 2. X-ray fluorescence analysis results.

\begin{tabular}{ccc}
\hline Received Catalyst & Weight (\%) & Range \\
\hline $\mathrm{Ni}$ & 9.847 & $\pm 0.014 \%$ \\
$\mathrm{Al}$ & 20.150 & $\pm 0.05 \%$ \\
$\mathrm{Ca}$ & 8.085 & $\pm 0.022 \%$ \\
Loss of ignition & 61.918 & - \\
\hline
\end{tabular}

\subsection{Test-Rig}

Tests for the evaluation of both $\mathrm{CO}_{2}$ capture and TAR conversion efficiency have been carried out through the bench-scale experimental rig illustrated in Figure 1, similar to the apparatus realized by Michel et al. and Rapagnà et al. [34,35]. The system consists essentially of the following areas:

- a syngas production section with a cylindrical bubbling fluidised bed gasifier, fed continuously with biomass, steam and nitrogen;

- a gas cleaning section with a cyclone and a high temperature ceramic candle filter in series;

- a reforming $-\mathrm{CO}_{2}$ capture section with a secondary fixed bed micro-reactor filled with the catalyst — sorbent powder and thermally controlled;

- another cleaning section consisting of a system of impingers kept at low temperature to favour TAR condensation;

- a syngas monitoring section with a volumetric gas-meter and controller and a gas-chromatograph.

The fluidized bed gasifier consists of an austenitic stainless steel cylindrical vessel of $80 \mathrm{~mm}$ internal diameter (ID), fitted with a sintered stainless steel porous distributor plate, and designed to allow a good gas distribution at all temperatures. The pressure drops through this plate are higher than $40 \%$ of those through the fluidized bed yet at ambient temperature, in order to guarantee a uniform gas distribution at every temperature. The entire reactor is located in a cylindrical electric furnace provided with temperature and heating rate control systems. Temperature within the reactor is measured by means of two thermocouples, one immersed in the bed and the other located under the distributor. The bed inventory is olivine sand.

The hazelnut shells reach the gasifier through an endless screw system powered by an electric motor; to facilitate the feed of biomass into the reactor and to avoid problems of agglomeration and choking, a constant nitrogen flow is fed continuously to the biomass inlet pipe (as proved by Rapagnà et al. [35]).

Water for the generation of steam is fed to an electrically heated boiler by means of a dosing pump at a constant flow rate. 
Figure 1. Scheme of the experimental system: (1) bubbling fluidized bed gasifier; (2) biomass feed system-hopper and screw feeder; (3) gasifying agents inlet system; (4) distilled $\mathrm{H}_{2} \mathrm{O}$ storage; (5) water pump; (6) electric steam generator; (7) cyclone; (8) torch; (9) ceramic candle filter; (10) secondary reactor; (11) TAR condensation system; (12) mass flow controller (13) vacuum pump; (14) cumulative gas flow meter; (15) gas-chromatograph (TCD).

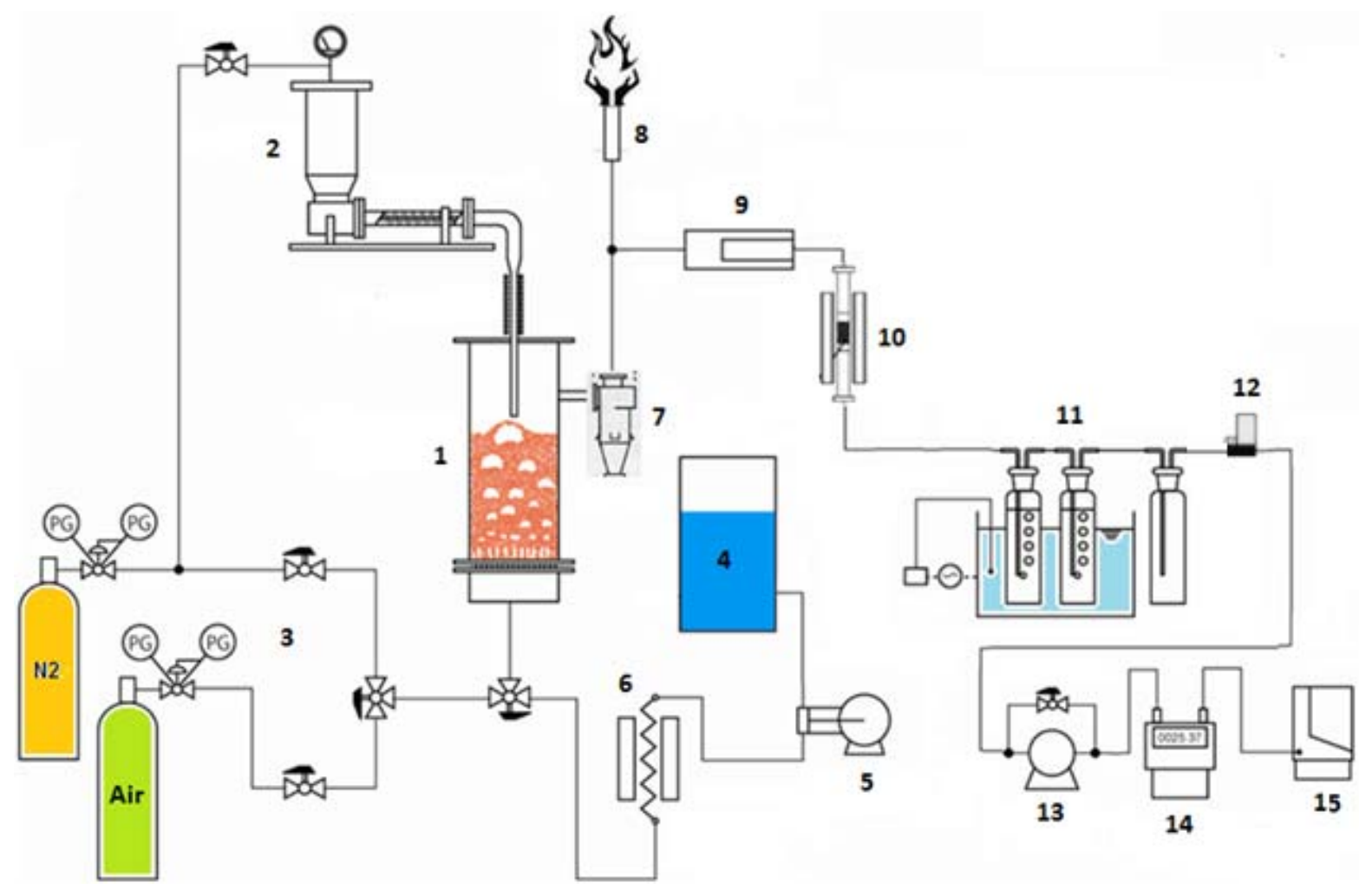

During the start-up the entire syngas generated by biomass gasification feeds a torch to be completely burned. When gasification process reaches the steady state condition a vacuum pump is switched on to feed the stainless steel microreactor for catalyst/sorbent test with a slipstream of raw gas. A heated ceramic filter assures that no fine particles reach the microreactor. The microreactor (filled with catalyst) is located in a cylindrical electric furnace provided with temperature and heating rate control systems. The temperature of the catalyst bed is measured by a thermocouple inside the bed. For each run the permanent gas yield is measured by means of a volumetric gas-meter, after separation of the condensate (water and organic phases) in a cold bath of isopropanol $\left(-15^{\circ} \mathrm{C}\right)$. According to the TAR guideline provided by the European Committee for Standardization, the raw gas passes through different impingers in series filled with isopropanol and placed in a thermostatic bath maintained at $-15^{\circ} \mathrm{C}$ by a chiller-thermocouple system. The flow-rate of the slipstream is controlled by a Bronkhorst - El Flow flow regulator downstream of the vacuum pump (Bronkhorst High-Tech B.V., Ruurlo, The Netherlands). At the end of every absorption phase the isopropanol full of TARs is collected and analysed. In particular the TARs are measured after each test by means of Agilent GC-MS 5975C gas-chromatograph with mass spectrometry (Agilent Technologies, Santa Clara, CA, USA). Gas products are analysed by VARIAN CP-4900 micro-GC gas-chromatograph (Varian Inc., Middelburg, The Netherlands). 


\section{Experimental Test}

Hazelnut shells were used for the gasification tests. The biomass elemental analysis is reported in Table 3. The preliminary analysis (moisture, ash, volatile matter and carbon) was carried out by means of a TGA (Mettler-Toledo International Inc., Columbus, OH, USA), the elemental analysis (CHNO) was carried out by means of a Leco $2000 \mathrm{CHN}$ analyzer (LECO Corporation, St Joseph, MI, USA), and the LHV by means of a Parr 6200 isoperibol oxygen bomb calorimeter (Thermo Fisher Scientific Inc., Waltham, MA, USA).

Table 3. Physical and chemical properties of biomass.

\begin{tabular}{cccc}
\hline Type & \multicolumn{3}{c}{ Hazelnut shells } \\
\hline Status & Raw & Dry & Dry-ash-free (daf) \\
Moisture (wt\%) & 7.9 & - & - \\
Ash (wt\%) & 1.16 & 1.26 & - \\
Volatile matter (wt\%) & 72.45 & 78.66 & 79.67 \\
Carbon $(w t \%)$ & 46.65 & 50.65 & 51.3 \\
Hydrogen $(w t \%)$ & 5.55 & 6.03 & 6.1 \\
Oxygen $(w t \%)$ & 38.74 & 42.06 & 42.6 \\
LHV $(\mathrm{kJ} / \mathrm{kg})$ & 17,228 & 18,727 & 18,966 \\
\hline
\end{tabular}

All tests of Sorption Enhanced Steam Reforming have been performed maintaining the gasifier temperature at $850^{\circ} \mathrm{C}$ and the steam/biomass (S/B) ratio equal to 0.8 (see Table 4 for the complete list of gasifier operative parameters). The nitrogen flow within the reactor has been set to guarantee the bed material fluidization.

Table 4. Gasifier operating condition.

\begin{tabular}{ccc}
\hline Item or Condition & Unit & Measure \\
\hline Olivine particle's diameter & $\mu \mathrm{m}$ & 351 \\
Olivine's density & $\mathrm{kg} / \mathrm{m}^{3}$ & 2640 \\
Hazelnut shells particle's diameter & $\mu \mathrm{m}$ & $800-2000$ \\
Hazelnut shells' density & $\mathrm{g} / \mathrm{mL}$ & 0.56 \\
Bed temperature & ${ }^{\circ} \mathrm{C}$ & 850 \\
Biomass feed rate & $\mathrm{g} / \mathrm{h}$ & 345.6 \\
S/B & $\mathrm{g}_{\text {vap }} / \mathrm{g}_{\text {biom }}$ & 0.8 \\
\hline
\end{tabular}

The secondary fixed bed reactor has been filled with $27 \mathrm{~g}$ of material ( $8 \mathrm{~g}$ of Ni commercial catalyst and $19 \mathrm{~g}$ of calcined dolomite) for nickel content $5 \%$ of the total.

Every cycle of the whole test has included the following phases (see Table 5 for the complete list of operative parameters of the phases):

1. Achievement of the nominal operative conditions: the bed material was heated by a continuous nitrogen flow $(0.5 \mathrm{NL} / \mathrm{min})$ until it was reached the temperature of $650{ }^{\circ} \mathrm{C}$;

2. Sorption Enhanced Steam Reforming: once reached the steady state condition of gasification the vacuum pump was powered with the flow regulator set to $0.3 \mathrm{NL} / \mathrm{min}$; 
3. Calcination of dolomite: the secondary reactor was fed by a $0.5 \mathrm{NL} / \mathrm{min}$ nitrogen stream and heated up to $850{ }^{\circ} \mathrm{C}$ in order to quantify the amount of $\mathrm{CO}_{2}$ absorbed during the sorption enhanced steam reforming phase;

4. Combustion of catalyst: the bed material, maintained at $850{ }^{\circ} \mathrm{C}$, was provided with a constant air stream (equal to $0.5 \mathrm{NL} / \mathrm{min}$ ) in order to estimate the rate of carbon deposition during the test;

5. Catalyst reduction: the material within the secondary reactor was fed with a continuous hydrogen stream $(0.5 \mathrm{NL} / \mathrm{min})$, maintained at $850{ }^{\circ} \mathrm{C}$ for $30 \mathrm{~min}$ and then cooled to ambient temperature.

Table 5. Summary of the operative temperatures and gas flows for all test phases.

\begin{tabular}{cccccc}
\hline Phase & $\begin{array}{c}\mathrm{T} \\
\left({ }^{\circ} \mathbf{C}\right)\end{array}$ & $\begin{array}{c}\mathbf{H}_{\mathbf{2}} \text { flow } \\
(\mathbf{N L} / \mathbf{m i n})\end{array}$ & $\begin{array}{c}\text { Air flow } \\
(\mathbf{N L} / \mathbf{m i n})\end{array}$ & $\begin{array}{c}\mathbf{N}_{\mathbf{2}} \text { flow } \\
(\mathbf{N L} / \mathbf{m i n})\end{array}$ & $\begin{array}{c}\text { Syngas flow } \\
\text { (NL/min) }\end{array}$ \\
\hline In. reduction & $0 \rightarrow 850$ & 0.5 & - & - & - \\
Heating & $0 \rightarrow 650$ & - & - & 0.5 & - \\
Sorption & 650 & - & - & - & 0.3 \\
Calcination & 850 & - & - & 0.5 & - \\
Combustion & 850 & - & 0.5 & - & - \\
Fin. reduction & $850 \rightarrow 0$ & 0.5 & - & - & - \\
\hline
\end{tabular}

\section{Result and Discussion}

\subsection{Baseline Tests}

All tests were performed after the fluidized bed reached the steady state conditions indicated in Table 4. Table 6 and Figure 2 show the reference gas composition and TAR concentration obtained in the tests without catalyst.

Table 6. Reference composition of the gas obtained by steam gasification of biomass at $850{ }^{\circ} \mathrm{C}$ (dry, $\mathrm{N}_{2}$ free).

\begin{tabular}{ccc}
\hline Element or compound & Vol. fraction $\left(\right.$ dry, $\mathbf{N}_{\mathbf{2}}$ free) & Standard deviation $(\boldsymbol{\sigma})$ \\
\hline $\mathrm{H}_{2}$ & 0.48 & 0.00727 \\
$\mathrm{CO}$ & 0.21 & 0.00365 \\
$\mathrm{CH}_{4}$ & 0.09 & 0.00436 \\
$\mathrm{CO}_{2}$ & 0.22 & 0.00302 \\
\hline
\end{tabular}

\subsection{Sorbent/Catalyst Tests}

The efficiency of the commercial nickel catalyst mixed with dolomite in both TAR conversion and $\mathrm{CO}_{2}$ sorption has been evaluated by means of $\mathrm{H}_{2}$ response curves. In case of sorption enhanced steam reforming, as described by Harrison et al. [33], response curves present a typical shape which can be divided in three sections. The first one is called "pre-breakthrough" and corresponds to the highest efficiency of $\mathrm{CO}_{2}$ sorption, water gas shift and TAR reforming reactions together and is represented by a plateau until the reactions are at equilibrium. After some time, depending on the amount of $\mathrm{CaO}$ and on $\mathrm{CO}_{2}$ partial pressure, carbonation reaction decreases its efficiency and the curve shows a rapid fall. 
This transient is the "breakthrough" section, characterized by an almost specular behaviour of $\mathrm{H}_{2}$ (decreasing) and $\mathrm{CO}_{2}$ (increasing). When carbonation offers no more contribution to TAR reforming reactions, hydrogen and carbon dioxide reach a new equilibrium, characterized by another plateau; this last section is called "post-breakthrough".

Figure 2. Reference TAR concentration in the gas obtained from steam gasification of biomass at $850{ }^{\circ} \mathrm{C}$ (dry, $\mathrm{N}_{2}$ free): (a) benzene, toluene, naphthalene; (b) phenanthrene, anthracene, xylene, styrene, phenol.

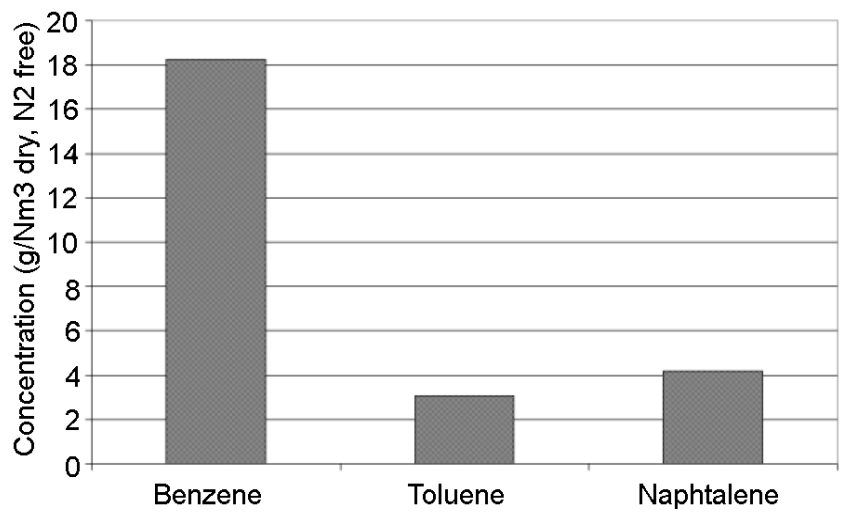

(a)

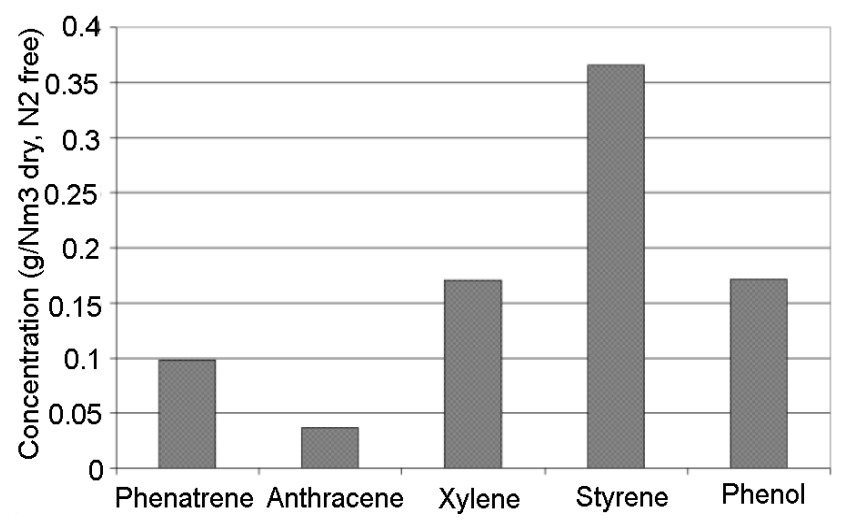

(b)

In Figures 3, the behaviour of $\mathrm{N}_{2}$-free content of raw gas principal components $\left(\mathrm{H}_{2}, \mathrm{CO}_{2}, \mathrm{CO}\right.$ and $\mathrm{CH}_{4}$ ) downstream Sorption Enhanced Steam Reforming is shown.

Figure $3 \mathrm{a}$ represents the $\mathrm{H}_{2}$ response curves of Ni catalyst-Dolomite SESR during four subsequent cycles. For all the curves it is possible to distinguish well the three previously described sections. The first cycle curve shows the best behaviour in $\mathrm{H}_{2}$ yield with values that reach $92 \%$ in the pre-breakthrough section (equal to the result achievable by thermodynamic analysis) and a successive softer decrease. The other cycles display instead an increasingly accentuated delay in reaching the initial plateau, a lower maximum value and a faster breakthrough transient.

The $\mathrm{CO}_{2}$ trends for the different cycles (Figure 3b) essentially confirm what already underlined by the $\mathrm{H}_{2}$ response curves, showing a strong decay in sorption efficiency even between the first two cycles.

The $\mathrm{CO}$ content behaviour (Figure 3c) proves the influence of the sorbent in water gas shift reaction activity. In the pre-breakthrough section the CO percentage is minimized due to both TAR reforming (that produces $\mathrm{CO}$ ) and contemporary WGS reactions, with efficiency getting worse during the subsequent cycles. Then in the post-breakthrough section the lack of absorption activity causes a reduced effect of WGS and a gradual increase of the CO content. Furthermore a more rapid decrease in TAR reforming reactions activity compared to water gas shift's one is observed during the cycles.

Finally, Figure $3 \mathrm{~d}$ confirms the behaviour of the other components content, highlighting the $\mathrm{Ni}$ catalyst decay in methane reforming during the subsequent cycles. Moreover $\mathrm{CH}_{4}$ behaviour can be used as reference to evaluate high hydrocarbon steam reforming. $3^{\text {th }}$ cycle trend is the one that best demonstrates the catalyst activity decay. 
Figure 3. Content within the raw gas (expressed as $\% \mathrm{vol} \mathrm{N}_{2}$-free) during four subsequent cycles of SESR.
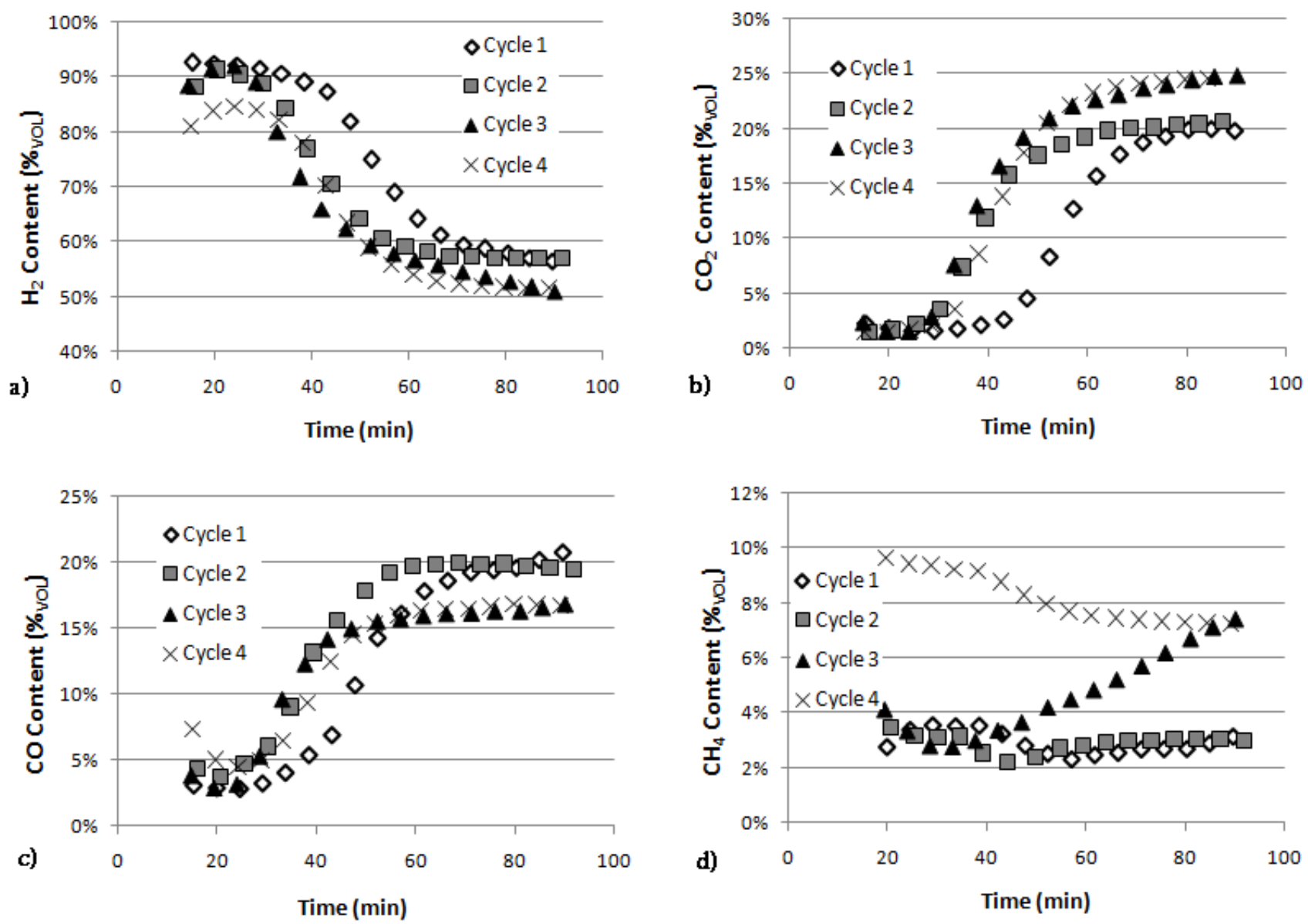

This decay is also visible from Figures 4 and Figure 5, which represent the TARs conversion rate for the sum of the detected TARs and for each of the following TAR classes:

- benzene;

- 1-ring: toluene (most abundant), xylene, styrene;

- phenol;

- 2-rings: naphthalene;

- 3-rings: phenanthrene, anthracene;

- 4-rings: pyrene.

TARs conversion rate has been calculated by comparing it to a no-reforming test performed under the same gasifier steady state conditions. Figure 4 shows values of total TARs conversion rate close to $100 \%$ for both the first and the second cycle. On the contrary, between the second and the third cycle, in agreement with $\mathrm{CH}_{4}$ content rise, a significant decrease (up to 53\%) is observed.

The graph of Figure 5 confirms the initial strong activity of $\mathrm{Ni} / \mathrm{Al}_{2} \mathrm{O}_{3}$ for each TAR class, with values of conversion rate exceeding by $99 \%$ on average, but also shows a subsequent great decrease especially for benzene and 1 ring hydrocarbons (toluene, xylene, and styrene). 
Figure 4. Total TARs conversion rates during the cycles.

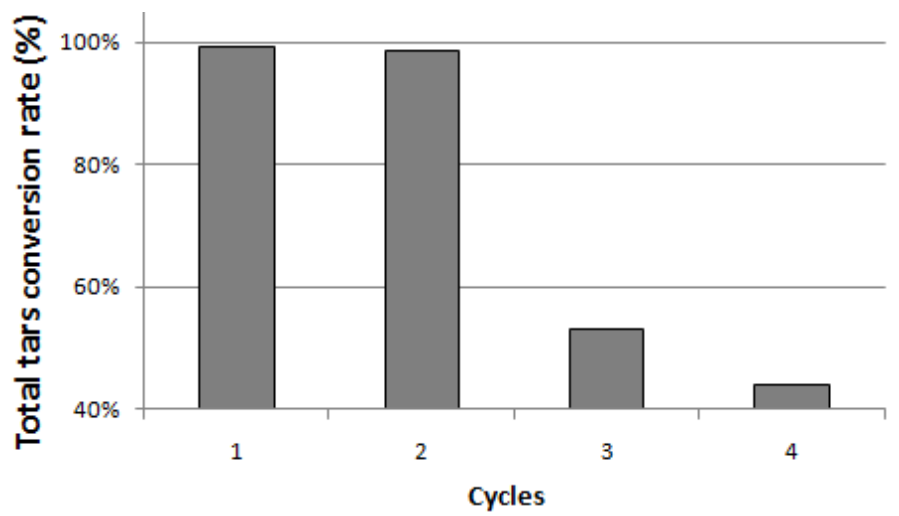

Figure 5. TAR conversion rate (\%) for single TAR classes during the cycles.

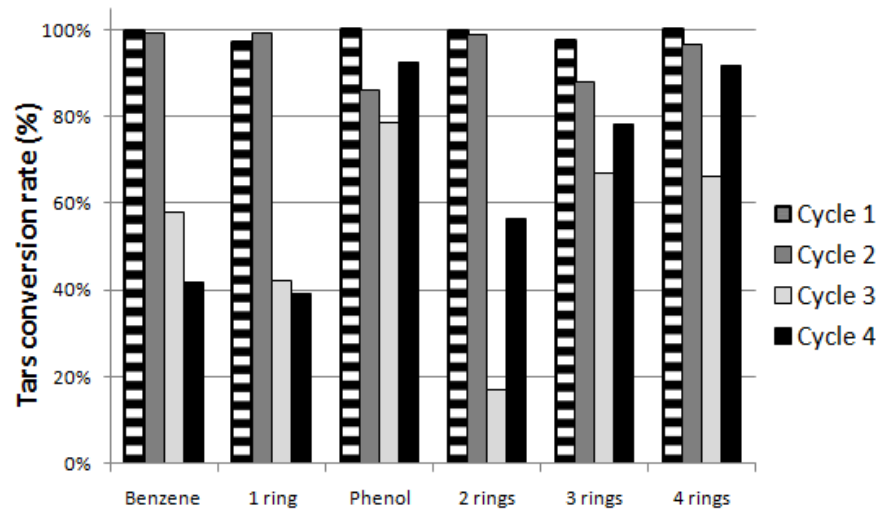

Then Figure 6 (reporting the TAR concentration within the gas stream for each class), showing large amounts of benzene and 1-ring TAR in the last two cycles compared to the others, justifies the low values of the reported total TARs conversion rate.

Dolomite behaviour through multiple $\mathrm{CO}_{2}$ capture and release cycles, clearly described by the response curves, was also confirmed by the measurement of the $\mathrm{CO}_{2}$ released during calcinations.

In Figure 7, the $\mathrm{CO}_{2}$ content behavior for each cycle expressed in moles per minute is reported. The total amount of released $\mathrm{CO}_{2}$ (obtained as integral of each curve) can be related to the total amount of $\mathrm{CO}_{2}$ captured during the previous phase without making significant mistakes. Furthermore calculation of the absorbed $\mathrm{CO}_{2}$ moles by mean of Figure 7 curves integral gives more accurate qualitative and quantitative information than the $\mathrm{CO}_{2}$ response curve (Figure 3b) because it's not dependent on time and on any possible small fluctuation in the nitrogen flow rate. It is easy to notice that going forward with the cycles the area subtended to the curves decreases.

This result can also be expressed in terms of total moles of released-absorbed $\mathrm{CO}_{2}$ and in terms of absorption efficiency, as summarized in Table 7.

Table 7. Results of calcination phase for all the cycles.

\begin{tabular}{ccccc}
\hline Efficiency Expression & Cycle 1 & Cycle 2 & Cycle 3 & Cycle 4 \\
\hline Moles of released $\mathrm{CO}_{2}(\mathrm{~mol})$ & 0.165 & 0.147 & 0.143 & 0.144 \\
Sorbent conversion $(\%)$ & 81.3 & 72.2 & 70.6 & 71.0 \\
Moles or released $\mathrm{CO}(\mathrm{mol})$ & 0.010 & 0.024 & 0.008 & 0.018 \\
\hline
\end{tabular}


Figure 6. TAR concentration ( $\mathrm{g} / \mathrm{Nm}^{3}$ dry, $\mathrm{N}_{2}$ free) for single $\mathrm{TAR}$ classes during the cycles.

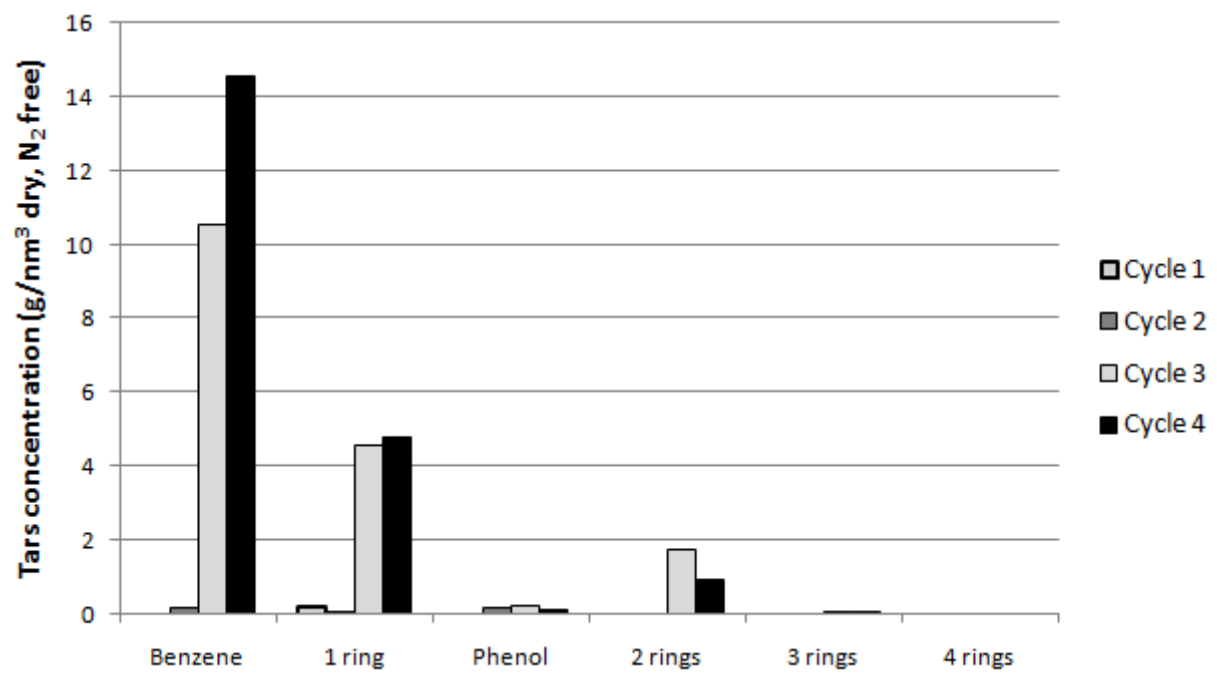

Figure 7. $\mathrm{CO}_{2}$ content within the $\mathrm{N}_{2}$ stream (expressed in moles per minute) for all cycles calcinations phase.

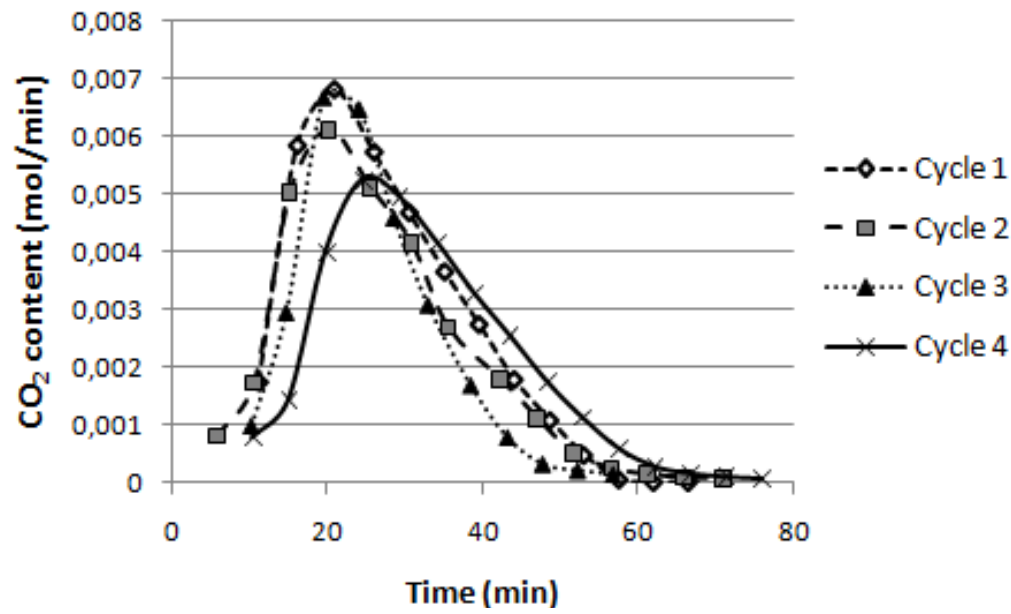

Absorption efficiency was calculated as the ratio between the moles of released $\mathrm{CO}_{2}$ and the total ones calculated stoichiometrically from carbonation reaction (equal to the moles of $\mathrm{CaO}$ in the bed material). Results show high efficiency during the first cycle ( $81.3 \%$ on average), followed by expected lower values (as already perceived in Figure 3). Hence its trend confirms the dolomite progressive loss of sorption capacity during cycles, often accompanied with structural modification, pore volume and surface area reduction, as widely reported in literature [13,24].

Table 7 also reports the total amount of $\mathrm{CO}$ detected within the gas stream during the calcination phase. Furthermore traces of $\mathrm{CO}_{2}$ within the air stream during the subsequent combustion phase have been detected. Presence of $\mathrm{CO}$ together with the detected $\mathrm{CO}_{2}$ traces give information about catalyst deactivation by carbon deposition. As a matter of fact $\mathrm{CO}$ can be only generated during calcination by reaction of carbon with $\mathrm{CO}_{2}$ in Boudouard's equilibrium. As a consequence, as already verified in literature [24], the presence of $\mathrm{CO}$ can partly justify the observed decay in catalyst efficiency. The use of a higher steam to carbon ratio could solve this problem. The decay of the catalyst activity could be due to the formation at high temperature of Ni aluminates that would not be 
reduced at $850{ }^{\circ} \mathrm{C}$, the amount of metallic nickel available as catalyst would be thus lower. For this reason XRD analysis of the spent sorbent/catalyst after tests was carried out. The results of the analysis are shown in Figure 8, no Ni aluminates were observed, the relevant phases are $\mathrm{CaO}, \mathrm{MgO}$ metallic $\mathrm{Ni}$ and Grossite $\left(\mathrm{CaAl}_{4} \mathrm{O}_{7}\right)$, and this last one is the binder of the commercial catalyst.

Figure 8. XRD analysis of the spent sorbent/catalyst after tests.

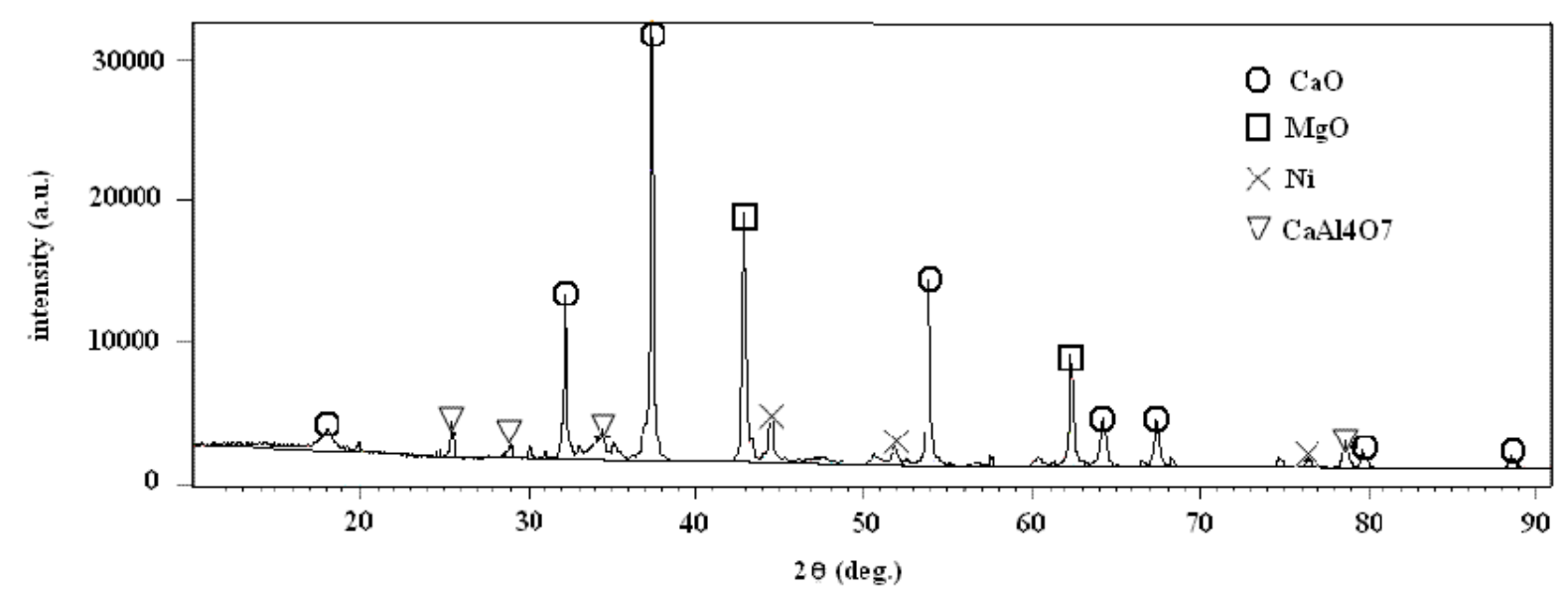

As a matter of fact it must be said that catalyst used for the tests has an amount of Ni of $16.6 \%$ that can be considered high.

Catalyst can suffer from metallic Ni thermal degradation and sintering as described in [36], especially during the regeneration phase in an air environment where higher temperatures are reached on the Ni surface during carbon combustion. It is also important to underline that $\mathrm{CO}_{2}$ absorption also decreases after four cycles which is a low number for a real industrial application.

\section{Conclusions}

In this work, the results obtained by catalytic steam reforming of a raw gas resulting from biomass gasification and simultaneous $\mathrm{CO}_{2}$ capture were presented and discussed. A mixture of commercial catalyst and calcined dolomite has been used for the experimental tests at $650{ }^{\circ} \mathrm{C}$. Results showed that total TAR conversion can be close to $100 \%$ and the volumetric percentage of hydrogen in the gas can reach $92 \%$, thanks to the enhancement of the water gas shift reaction due to the presence of the $\mathrm{CO}_{2}$ sorbent. Multi-cycle tests anyway showed a fast decrease in the catalyst activity both for the steam reforming of methane and for the TAR reforming: the methane volumetric percentage in the gas was close to the base tests without catalyst, while TAR conversion was lower than $50 \%$ at the 4 th cycle. This deactivation could be partially justified by carbon formation on the catalytic site, observed at the end of each test during the regeneration of the catalyst and sorbent. Another possible explanation could be the thermal degradation and sintering during the regeneration phase in air environment where higher temperatures are reached on the $\mathrm{Ni}$ surface during carbon combustion. To clarify this phenomenon, further tests seem necessary, with a higher steam to carbon ratio or a milder regeneration with steam instead of air. 


\section{Acknowledgements}

The authors acknowledge the financial support of European Contract ID 299732 (regarding the research project UNIfHY, UNIQUE For Hydrogen production, under the topic SP1-JTI-FCH.2011.2.3: Biomass-to-hydrogen (BTH) thermal conversion process) funded by the European Union, Seventh Framework Programme, Fuel Cells and Hydrogen Joint Technologies Initiative (FP7, FCH-JU).

\section{Conflict of Interest}

The authors declare no conflict of interest.

\section{References}

1. Orecchini, F.; Bocci, E. Biomass to hydrogen for the realization of closed cycles of energy resources. Energy 2007, 32, 1006-1011.

2. Abu El-Rub, Z.; Bramer, E.A.; Brem, G. Experimental comparison of biomass chars with other catalysts for tar reduction. Fuel 2008, 87, 2243-2252.

3. Belgiorno, V.; De Feo, G.; Della Rocca, C.; Napoli, R.M.A. Energy from gasification of solid wastes. Waste Manag. 2003, 23, 1-15.

4. Anis, S.; Zainal, Z.A. Tar reduction in biomass producer gas via mechanical, catalytic and thermal methods: A review. Renew. Sustain. Energy Rev. 2011, 15, 2355-2377.

5. Devi, L.; Ptasinski, K.J.; Janssen, F.J.J.G.; van Paasen, S.V.B.; Bergman, P.C.A.; Kiel, J.H.A. Catalytic decomposition of biomass tars: Use of dolomite and untreated olivine. Renew. Energy 2005, 30, 565-587.

6. Swierczynski, D.; Courson, C.; Kiennemann, A. Study of steam reforming of toluene used as model compound of tar produced by biomass gasification. Chem. Eng. Process. Process Intensif. 2008, 47, 508-513.

7. Li, C.; Suzuki, K. Tar property, analysis, reforming mechanism and model for biomass gasification-An overview. Renew. Sustain. Energy Rev. 2009, 13, 594-604.

8. Kirnbauer, F.; Wilk, V.; Kitzler, H.; Kern, S.; Hofbauer, H. The positive effects of bed material coating on tar reduction in a dual fluidized bed gasifier. Fuel 2012, 95, 553-562.

9. Martavaltzi, C.S.; Lemonidou, A.A. Hydrogen production via sorption enhanced reforming of methane: Development of a novel hybrid material-Reforming catalyst and $\mathrm{CO}_{2}$ sorbent. Chem. Eng. Sci. 2010, 65, 4134-4140.

10. Johnsen, K.; Ryu, H.J.; Grace, J.R.; Lim, C.J. Sorption-enhanced steam reforming of methane in a fluidized bed reactor with dolomite as $\mathrm{CO}_{2}$-acceptor. Chem. Eng. Sci. 2006, 61, 1195-1202.

11. Johnsen, K.; Grace, J.R.; Elnashaie, S.S.E.H.; Kolbeinsen, L.; Eriksen, D. Modeling of sorption-enhanced steam reforming in a dual fluidized bubbling bed reactor. Ind. Eng. Chem. Res. 2006, 45, 4133-4144.

12. Di Carlo, A.; Bocci, E.; Zuccari, F.; Dell'Era, A. Numerical investigation of sorption enhanced steam methane reforming process using computational fluid dynamics Eulerian-Eulerian code. Ind. Eng. Chem. Res. 2010, 49, 1561-1576. 
13. Florin, N.H.; Harris, A.T. Enhanced hydrogen production from biomass with in situ carbon dioxide capture using calcium oxide sorbents. Chem. Eng. Sci. 2008, 63, 287-316.

14. Orecchini, F.; Bocci, E.; Di Carlo, A. MCFC and microturbine power plant simulation. J. Power Sources 2006, 160, 835-841.

15. Orecchini, F.; Bocci, E.; Di Carlo, A. Process simulation of a neutral emission plant using chestnut's coppice gasification and molten carbonate fuel cells. J. Fuel Cell Sci. Technol. 2008, 5, 021015:1-021015:9.

16. Bocci, E.; Di Carlo, A.; Marcelo, D. Power plant perspectives for sugarcane mills. Energy 2009, 34, 689-698.

17. Farhad, S.; Hamdullahpur, F.; Yoo, Y. Performance evaluation of different configurations of biogas-fuelled SOFC micro-CHP systems for residential applications. Int. J. Hydrog. Energy 2010, 35, 3758-3768.

18. Di Carlo, A.; Bocci, E.; Dell'Era, A. Comparison by the use of numerical simulation of a MCFC-IR and a MCFC-ER when used with syngas obtained by atmospheric pressure biomass gasification. Int. J. Hydrog. Energy 2011, 36, 7976-7984.

19. Di Carlo, A.; Bocci, E.; Naso, V. Process simulation of a SOFC and double bubbling fluidized bed gasifier power plant. Int. J. Hydrog. Energy 2013, 38, 532-542.

20. Di Carlo, A.; Borello, D.; Bocci, E. Process simulation of a hybrid SOFC/mGT and enriched air/steam fluidized bed gasifier power plant. Int. J. Hydrog. Energy 2013, 38, 5857-5874.

21. Yan, Z.; Zhao, P.; Wang, J.; Dai, Y. Thermodynamic analysis of an SOFC-GT-ORC integrated power system with liquefied natural gas as heat sink. Int. J. Hydrog. Energy 2013, 38, 3352-3363.

22. Koppatz, S.; Pfeifer, C.; Rauch, R.; Hofbauer, H.; Marquard-Moellenstedt, T.; Specht, M. $\mathrm{H}_{2}$ rich product gas by steam gasification of biomass with in situ $\mathrm{CO}_{2}$ absorption in a dual fluidized bed system of $8 \mathrm{MW}$ fuel input. Fuel Process. Technol. 2009, 90, 914-921.

23. Hawthorne, C.; Dieter, H.; Bidwe, A.; Schuster, A.; Scheffknecht, G.; Unterberger, S.; Käß, M. $\mathrm{CO}_{2}$ capture with $\mathrm{CaO}$ in a $200 \mathrm{~kW}$ th dual fluidized bed pilot plant. Energy Procedia 2011, 4, 441-448.

24. Di Felice, L.; Courson, C.; Jand, N.; Gallucci, K.; Foscolo, P.U.; Kiennemann, A. Catalytic biomass gasification: Simultaneous hydrocarbons steam reforming and $\mathrm{CO}_{2}$ capture in a fluidised bed reactor. Chem. Eng. J. 2009, 154, 375-383.

25. Abanades, J.C.; Alvarez, D. Conversion limits in the reaction of $\mathrm{CO}_{2}$ with lime. Energy Fuels 2003, 17, 308-315.

26. Borgwardt, R.H. Calcium oxide sintering in atmospheres containing water and carbon dioxide. Ind. Eng. Chem. Res. 1989, 28, 493-500.

27. Martavaltzi, C.S.; Lemonidou, A.A. Development of new $\mathrm{CaO}$ based sorbent materials for $\mathrm{CO}_{2}$ removal at high temperature. Microporous Mesoporous Mater. 2008, 110, 119-127.

28. Li, Z.; Cai, N.; Huang, Y. Effect of preparation temperature on cyclic $\mathrm{CO}_{2}$ capture and multiple carbonation-calcination cycles for a new Ca-based $\mathrm{CO}_{2}$ sorbent. Ind. Eng. Chem. Res. 2006, 45, 1911-1917.

29. Di Felice, L.; Courson, C.; Foscolo, P.U.; Kiennemann, A. Iron and nickel doped alkaline-earth catalysts for biomass gasification with simultaneous tar reformation and $\mathrm{CO}_{2}$ capture. Int. J. Hydrog. Energy 2011, 36, 5296-5310. 
30. Felice, L.D.; Courson, C.; Foscolo, P.U.; Kiennemann, A. Modified dolomite in biomass gasification with simultaneous tar reformation and $\mathrm{CO}_{2}$ capture: Effect of metal loading. IOP Conf. Ser. Mater. Sci. Eng. 2011, 19, doi:10.1088/1757-899X/19/1/012009.

31. Monarca, D.; Colantoni, A.; Cecchini, M.; Longo, L.; Vecchione, L.; Carlini, M.; Manzo, A. Energy characterization and gasification of biomass derived by hazelnut cultivation: Analysis of produced syngas by gas chromatography. Math. Probl. Eng. 2012, 2012, doi: 10.1155/2012/102914.

32. Lopez Ortiz, A.; Harrison, D.P. Hydrogen production using sorption-enhanced reaction. Ind. Eng. Chem. Res. 2001, 40, 5102-5109.

33. Harrison, D.P. Sorption-enhanced hydrogen production: A review. Ind. Eng. Chem. Res. 2008, 47, 6486-6501.

34. Michel, R.; Rapagnà, S.; Burg, P.; Di Celso, G.M.; Courson, C.; Zimny, T.; Gruber, R. Steam gasification of Miscanthus X Giganteus with olivine as catalyst production of syngas and analysis of tars (IR, NMR and GC/MS). Biomass Bioenergy 2011, 35, 2650-2658.

35. Rapagná, S.; Provendier, H.; Petit, C.; Kiennemann, A.; Foscolo, P.U. Development of catalysts suitable for hydrogen or syn-gas production from biomass gasification. Biomass Bioenergy 2002, 22, 377-388.

36. Bartholomew, C.H. Mechanisms of catalyst deactivation. Appl. Catal. A Gen. 2001, 212, 17-60.

(C) 2013 by the authors; licensee MDPI, Basel, Switzerland. This article is an open access article distributed under the terms and conditions of the Creative Commons Attribution license (http://creativecommons.org/licenses/by/3.0/). 